\title{
Evaluation of Plant Growth Regulator, Immunity and DNA Fingerprinting of Biofield Energy Treated Mustard Seeds (Brassica juncea)
}

\author{
Mahendra Kumar Trivedi ${ }^{1}$, Alice Branton ${ }^{1}$, Dahryn Trivedi $^{1}$, Gopal Nayak ${ }^{1}$, \\ Sambhu Charan Mondal ${ }^{2}$, Snehasis Jana ${ }^{2, *}$ \\ ${ }^{1}$ Trivedi Global Inc., Henderson, USA \\ ${ }^{2}$ Trivedi Science Research Laboratory Pvt. Ltd., Bhopal, Madhya Pradesh, India
}

Email address:

publication@trivedisrl.com (S. Jana)

\section{To cite this article:}

Mahendra Kumar Trivedi, Alice Branton, Dahryn Trivedi, Gopal Nayak, Sambhu Charan Mondal, Snehasis Jana. Evaluation of Plant Growth Regulator, Immunity and DNA Fingerprinting of Biofield Energy Treated Mustard Seeds (Brassica juncea). Agriculture, Forestry and Fisheries. Vol. 4, No. 6, 2015, pp. 269-274. doi: 10.11648/j.aff.20150406.16

\begin{abstract}
Among the oilseeds grown around the world, mustard is one of the important crop worldwide due to its wide adaptability and high yielding capacity. Owing to the importance of its utilities as condiment, cooking oil and some medical aids, the demand for its seed production is too high. The present study was carried out to evaluate the impact of Mr. Trivedi's biofield energy treatment on mustard (Brassica juncea) for its growth-germination of seedling, glutathione (GSH) content in leaves, indole acetic acid (IAA) content in shoots and roots and DNA polymorphism by random amplified polymorphic-DNA (RAPD). The sample of $B$. juncea was divided into two groups. One group was remained as untreated and coded as control, while the other group was subjected to Mr. Trivedi's biofield energy treatment and referred as the treated sample. The growth-germination of $B$. juncea seedling data exhibited that the biofield treated seeds were germinated faster on day 5 as compared to the control (on day between 7-10). The shoot and root length of seedling were slightly increased in the treated seeds of 10 days old with respect to untreated seedling. Moreover, the major plant antioxidant i.e. GSH content in mustard leaves was significantly increased by $206.72 \%(p<0.001)$ as compared to the untreated sample. Additionally, the plant growth regulatory constituent i.e. IAA level in root and shoot was increased by $15.81 \%$ and $12.99 \%$, respectively with respect to the control. Besides, the DNA fingerprinting data using RAPD revealed that the treated sample showed an average $26 \%$ of DNA polymorphism as compared to the control. The overall results envisaged that the biofield energy treatment on mustard seeds showed a significant improvement in germination, growth of roots and shoots, GSH and IAA content in the treated sample. In conclusion, the biofield energy treatment of mustard seeds could be used as an alternative way to increase the production of mustard.
\end{abstract}

Keywords: Mustard, Biofield Energy Treatment, Seedling, RAPD, Glutathione, Indole Acetic Acid

\section{Introduction}

Indian mustard (Brassica juncea) is a winter oilseed crop grown across the Northern Indian plains. Among the various oilseed crops, it is one of the important because of its potential utilities in the growing biofuels industries [1]. Mustard seed is widely used as a condiment and as an edible oil. The pungency of mustard oil is due to the presence of allyl-isothiocyanate. The low pungency of mustard oil can be obtained after inactivating the myrosinase enzyme present in it and used as a filler component in various processed meat products [2].
Glucosinolates are the major class of bioactive phytocontituents mainly rich in mustard. The hydrolytic product of glucosinolates plays an important role in plant defense against microorganisms and insects. However, it itself may act as nutrients as an essential component of nitrogen and sulfur [3]. Based on the literature, it was reported that the mustard seeds extract have the potential chemo-preventive and chemotherapeutic activities in vitro by scavenging the hydroxyl radicals, it also induces apoptosis of cancer cells [4]. Several studies have reported the antioxidant activities of mustard seeds extract $[1,5]$. Rance and Morisset et al. reported the allergic reactions of mustard such as atopic dermatitis, 
urticaria and angioedema accounts $1.1 \%$ of total food allergy in children $[6,7]$. The agricultural productivity depends on the most vital abiotic stress factor; salinity i.e. dissolved salts in water. The metabolic impairment in the plant cell occurs due to the osmotic and toxic effects of salt concentration in water. The different levels of salinity have affected the lipid components of mustard seeds. With increasing the salinity, phospholipids and glycolipids content were increased, while total and neutral lipids content were declined [8]. Generation of reactive oxygen species (ROS) is the main output of such metabolic impairment during salinity stress $[9,10]$. The ROS such as superoxide radical $\left(\mathrm{O}^{2-}\right)$, hydrogen peroxide $\left(\mathrm{H}_{2} \mathrm{O}_{2}\right)$, and hydroxyl radical $\left(\mathrm{OH}^{-}\right)$are produced through the reduction of molecular $\mathrm{O}_{2}$ during aerobic metabolism in mitochondria. Apart from the metabolic derived ROS, plant cell also produces singlet oxygen $\left({ }^{1} \mathrm{O}_{2}\right)$ in the chloroplast during photosynthesis [11, 12]. Among the various antioxidant pathways, the ascorbate-glutathione (ASC-GSH) cycle has been played an important role [13]. In plants, GSH is crucial for biotic and abiotic stress management. It is a pivotal component of the ASC-GSH cycle, a system that reduces poisonous hydrogen peroxide produced during photorespiration in peroxisomes. GSH and GSH-dependent enzymes represent a regulated defense against oxidative stress not only against ROS but also against their toxic products. Recent advances in molecular biology, development of polymerase chain reaction (PCR), and DNA sequencing have resulted in a powerful technique that can be used for the characterization of genetic diversity. Besides, the genetic diversity can also be assessed by the study of morphoagronomic variability for plant breeders. For characterization of genetic profile a powerful tool has been developed as the molecular marker, so called DNA fingerprinting [14].

The National Center for Complementary and Integrative Health (NCCIH), allows the use of Complementary and Alternative Medicine (CAM) therapies like biofield energy as an alternative in the healthcare field. About $36 \%$ of US citizens regularly use some form of CAM [15], in their daily activities. CAM embraces numerous energy-healing therapies; biofield therapy is one of the energy medicine used worldwide to improve the overall human health. Mr. Trivedi's unique biofield treatment (The Trivedi effect ${ }^{\circledR}$ ) has been extensively contributed in scientific communities in the field of agricultural science [16-19] and chemical science [20]. Due to the necessity of mustard as the food resource, and to improve the overall productivity of mustard plants an effective control measure need to be established. Under these circumstances, the present work was undertaken to evaluate the effect of biofield energy treatment on mustard in relation to germination growth in seedlings, level of GSH and IAA and the molecular analysis using DNA fingerprinting.

\section{Materials and Methods}

The Brassica juncea (B. juncea) seeds were distributed into two parts. One part was remained as control, no treatment was provided. The other part was subjected to $\mathrm{Mr}$.
Trivedi's biofield energy treatment and considered as treated. The random amplified polymorphic DNA (RAPD) analysis was done by Ultrapure Genomic DNA Prep Kit; Cat KT 83 (Bangalore Genei, India).

\subsection{Biofield Energy Treatment Strategy}

The treated sample of mustard seeds was subjected to $\mathrm{Mr}$. Trivedi's biofield treatment under ambient conditions. Mr. Trivedi provided the treatment to the seeds through his inherent unique energy transmission process without touch. The treated sample was assessed for growth germination of seedlings, glutathione (GSH) level and indole acetic acid (IAA) content in roots and shoots of the mustard plant.

\subsection{Growth Germination of Mustard Seedlings}

Control and treated mustard seeds (B. juncea) were soaked in distilled water separately. The water soaked seeds were wrapped with moist filter paper and kept in darkness at $20^{\circ} \mathrm{C}$ for germination. The percent of germinated seeds and length of roots and shoots in seedling were observed.

\subsection{Measurement of Glutathione in Mustard Leaves}

The extraction and estimation of GSH levels in plant leaves were followed as per standard method by Moron et al. 1979 . For the extraction of GSH, approximately $5 \mathrm{gm}$ of mustard leaves were crushed and mixed with $5 \mathrm{~mL}$ of $80 \%$ chilled methanol (as a solvent). Then the extract was sonicated for about 10 minutes. Then $1 \mathrm{~mL}$ of $5 \%$ trichloroacetic acid (TCA) was added to the extract. This sample was used for the analysis of GSH content. The GSH levels were estimated as per Moron et al. and TCA was taken as blank [21].

\subsection{Measurement of Indole Acetic Acid (IAA) Content in Shoots and Roots of Mustard Seedlings}

The extraction and analysis of IAA were done using Tang and Bonner's method. Freshly prepared Salkowski's reagent was used for the detection of IAA content in shoots and roots of mustard seedlings. For the extraction of IAA, approximate $200 \mathrm{mg}$ plant tissue (shoots and roots) was grinded with $5 \mathrm{~mL}$ of $80 \%$ chilled methanol. The extract was filtered through Whatman filter paper (No. 1). After filtration the final volume of the extract was made upto $10 \mathrm{~mL}$ using $80 \%$ cold methanol. Optical density was measured after 30 minutes at $530 \mathrm{~nm}$ using ultra-violet visible spectrophotometer [22].

\subsection{Isolation of Plant Genomic DNA Using CTAB Method}

After germination when the plants were reached the appropriate stage, leaves disc were harvested from each plant. Genomic DNA was isolated according to standard cetyl-trimethyl-ammonium bromide (CTAB) method [23]. Approximate $200 \mathrm{mg}$ of plant tissues (seeds) were grinded to a fine paste in approximately $500 \mu \mathrm{L}$ of CTAB buffer. The mixture (CTAB/plant extract) was transferred to a microcentrifuge tube, and incubated for about $15 \mathrm{~min}$ at $55 \mathrm{oC}$ in a recirculating water bath. After incubation, the 
mixture was centrifuged at $12000 \mathrm{~g}$ for $5 \mathrm{~min}$ and the supernatant was transferred to a clean microcentrifuge tube. After mixing with chloroform and iso-amyl alcohol followed by centrifugation the aqueous layers were isolated which contains DNA. Then, ammonium acetate followed by chilled absolute ethanol were added, to precipitate the DNA content and stored at $-20^{\circ} \mathrm{C}$. The RNase treatment was provided to remove any RNA material followed by washing with DNA free sterile solution. The quantity of genomic DNA was measured at $260 \mathrm{~nm}$ using spectrophotometer [24].

\subsection{Random Amplified Polymorphic DNA (RAPD) Analysis}

DNA concentration was considered about $25 \mathrm{ng} / \mu \mathrm{L}$ using distilled deionized water for the polymerase chain reaction (PCR) experiment. The RAPD analysis was performed on the treated mustard seeds using five RAPD primers, which were labelled as RPL 4A, RPL 5A, RPL 6A, RPL 13A, and RPL 19A. The PCR mixture including $2.5 \mu \mathrm{L}$ each of buffer, 4.0 $\mathrm{mM}$ each of dNTP, $2.5 \mu \mathrm{M}$ each of primer, $5.0 \mu \mathrm{L}$ (approximately $20 \mathrm{ng}$ ) of each genomic DNA, 2U each of Thermus aquaticus (Taq) polymerase, $1.5 \mu \mathrm{L}$ of $\mathrm{MgCl}_{2}$ and $9.5 \mu \mathrm{L}$ of water in a total of $25 \mu \mathrm{L}$ with the following PCR amplification protocol; initial denaturation at $94^{\circ} \mathrm{C}$ for $5 \mathrm{~min}$, followed by 40 cycles of annealing at $94^{\circ} \mathrm{C}$ for $1 \mathrm{~min}$, annealing at $36^{\circ} \mathrm{C}$ for $1 \mathrm{~min}$, and extension at $72^{\circ} \mathrm{C}$ for $2 \mathrm{~min}$. Final extension cycle was carried out at $72^{\circ} \mathrm{C}$ for $10 \mathrm{~min}$. Amplified PCR products (12 $\mu \mathrm{L}$ of each) from control and treated samples were loaded on to $1.5 \%$ agarose gel and resolved by electrophoresis at 75 volts. Each fragment was estimated using 100 bp ladder (Genei ${ }^{\mathrm{TM}}$; Cat \# RMBD19S). The gel was subsequently stained with ethidium bromide and viewed under UV-light [25]. Photographs were documented subsequently. The following formula was used for calculation of percentage of polymorphism.

$$
\text { Percent polymorphism }=\mathrm{A} / \mathrm{B} \times 100
$$

Where, $\mathrm{A}=$ number of polymorphic bands in treated plant; and $\mathrm{B}=$ number of polymorphic bands in control plant.

\section{Statistical Analysis}

Data from GSH content in mustard leaves were expressed as Mean \pm S.E.M. and analyzed through a Student's t-test to ascertain statistical differences between control and treated mustard seeds at the end of the experiment. A probability level of $p<0.05$ was considered as statistically significant as compared to the control.

\section{Results and Discussion}

\subsection{Growth Germination of Mustard Seedlings}

Allelopathy is the process of plant communication system through the direct or indirect, detrimental or advantageous effects of one plant to another. They communicate through the release of allelochemicals i.e. the secondary metabolites or waste products of plants into the environment through leaching, root exudation, volatilization and decomposition of plant residues. The mustard plant is belongs to Brassicaceae family cited as allelopathic crop [26]. The growth germination of mustard seedling data of control and treated samples are shown in Table 1.

Table 1. Growth-germination of mustard (Brassica juncea) seedlings.

\begin{tabular}{lllll}
\hline \multirow{2}{*}{ Group } & $\begin{array}{l}\text { Germination } \\
\text { (Day) }\end{array}$ & $\begin{array}{l}\text { Germination } \\
(\%)\end{array}$ & $\begin{array}{l}\text { Length }(\mathbf{c m}) \\
\text { (Mean } \pm \text { S.E.M.) }\end{array}$ \\
\cline { 4 - 5 } & & 65 & $8.88 \pm 0.16$ & $5.73 \pm 0.05$ \\
Control & $7-10^{\text {th }}$ & 100 & $8.91 \pm 0.25$ & $5.78 \pm 0.10$ \\
Treated & $5^{\text {th }}$ & $100 t$ & Root \\
\hline
\end{tabular}

$\mathrm{n}=100$ (Shoot); $\mathrm{n}=65$ (Root); S.E.M.: Standard error of mean

It was found that the control seeds of $B$. juncea were germinated by $65 \%$ between days $7-10$, while the biofield treated seeds were germinated on day 5 with $100 \%$ germination. After germination, on day $10^{\text {th }}$ the mustard plants shoot and roots were measured. The shoot length in control sample was $8.88 \mathrm{~cm}$ and in treated sample it was $8.91 \mathrm{~cm}(\mathrm{n}=100)$. The shoot length in the treated sample was slightly increased as compared to the control. Moreover, the length of root in control sample was $5.73 \mathrm{~cm}$ and in the treated sample it was $5.78 \mathrm{~cm}(\mathrm{n}=65)$. The root length in the treated sample was also slightly increased with respect to the control. The seeds of the majority of plant species have failed to germinate due to salt and osmotic stresses that may attribute either osmotic effects or specific ion toxicities towards seedling development. Establishment of the seedling is a critical stage in crop production that depends on the biochemical and physiological structures of seed. For faster and good development of seedling it is necessary a good physical strength and health of seeds to utilized essential nutrient during germination and early growth of seedling [8, 27]. Based on the findings, it is assumed that the early germination in biofield energy treated sample may be due to the increase in the ability of oxygen mediated metabolism to fight against stress that ultimately shortens the germination time as compared with the untreated seeds. Moreover, may be the biofield treated seeds protect themselves from allelopathic harmful effect from the environment. Hence, the treated seeds were germinated faster and the growth of roots and shoots were increased as compared to the untreated seeds.

\subsection{Measurement of Glutathione in Mustard Leaves}

The level of endogenous GSH content in leaves of both control and treated samples are illustrated in Table 2.

Sulfur is an essential component of all living organisms for protein synthesis. It is the integral constituent of various amino acids and cellular endogenous components like GSH. GSH ( $\gamma$-L-glutamyl-L-cysteinylglycine) is sulfur containing thiol tripeptide, found in most of the organisms including plants. Deficiency of sulfur retard the growth of shoot, while did not affect the growth of the roots [13, 28]. The concentration of endogenous GSH was $0.29 \pm 0.006 \mathrm{mM}$ in control group, whereas it was increased to $0.89 \pm 0.009 \mathrm{mM}$ 
$(n=4)$ in the treated group. The result indicated that the GSH level in mustard leaves were increased significantly $(p<0.001)$ by $206.72 \%$ in the biofield energy treated sample as compared to the naive (Table 2).

Table 2. The glutathione (GSH) level in the leaves of mustard (Brassica juncea).

\begin{tabular}{llllll}
\hline \multirow{2}{*}{ Group } & \multicolumn{2}{l}{ Endogenous GSH $(\mathbf{m M})$} & & $\begin{array}{l}\text { Mean GSH (mM) } \\
\text { (Mean } \pm \text { S.E.M.) }\end{array}$ \\
\cline { 2 - 5 } & Sample 1 & Sample 2 & Sample 3 & Sample 4 & $0.29 \pm 0.006$ \\
Control & 0.29 & 0.29 & 0.28 & 0.30 & $0.89^{*} \pm 0.009$ \\
Treated & 0.92 & 0.89 & 0.88 & 0.90 & 206.72 \\
\hline
\end{tabular}

S.E.M.: Standard error of mean; $\mathrm{n}=4 ; * p \leq 0.001$

As literature reported that mustard seeds extract have the chemo-preventive and chemotherapeutic activity by scavenging free radicals and induced death of cancerous cells by apoptosis [4]. This study revealed, the significant improvement of GSH in mustard leaves after biofield energy treatment. Hence, it is assumed that the increase in GSH content in the biofield treated sample might accelerate the rate of free radical scavenging activity. Besides, the chemo-preventive activity of mustard seeds extract on cervix cancer was reported by Gagandeep and their coresearcher [29]. It is expected that the biofield treated mustard seeds in the diet may contribute better ability to reduce the risk of cancer incidence due to its chemopreventive effect in the human population. Germination of seeds is the rate limiting factor in oxidative stress condition in plant cells. GSH is one of vital antioxidant in plant cells and plays a crucial role to plants defense system. Additionally, this data was well supported with early germination of mustard seedling in the biofield treated group (Table 1). Soil and water are polluted day by day due to heavy-metals derived by mining and from burning of fossil fuels. Plants like mustard have an important mechanistic pathway to detoxify heavy-metals through sequestration with heavy-metal with GSH [30]. This polluted soil and water cannot be chemically degraded or biodegraded by microorganisms. An alternative biological approach to deal with this problem is called phytoremediation, i.e. cultivation of mustard plants to clean up polluted waters and soils. Many studies have reported that live mustard plant tissues such as seeds and roots, contain a compound that acts as soil biofumigants by killing nematodes and pathogenic fungi [31].

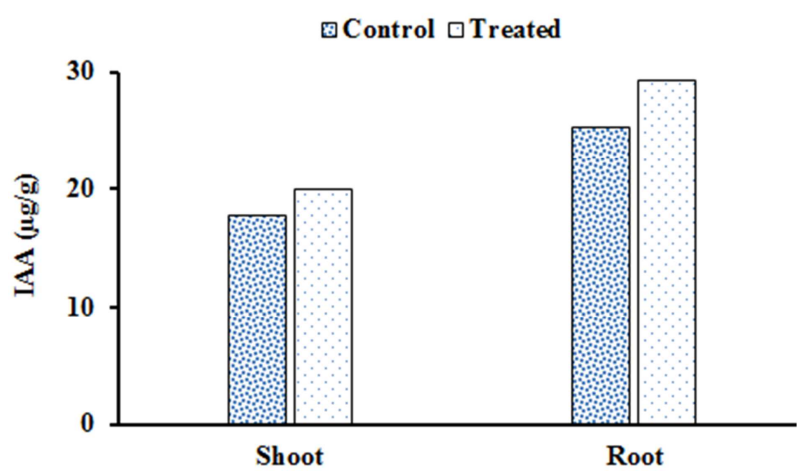

Figure 1. The indole acetic acid (IAA) content in shoots and roots of mustard (Brassica juncea).

\subsection{Measurement of Indole Acetic Acid (IAA) Content in Shoots and Roots of Mustard Seedlings}

IAA is one of the main constituents of plant growth substance i.e. auxin produced by several plant-associated commensal bacteria. The production of auxin is the key factor for determination of plant pathogenicity. Fewer chances of plant infection due to more level of IAA content in plants [32]. The IAA content in mustard shoots and roots of both control and treated samples are shown in Fig. 1.

In this experiment, the IAA content in mustard roots was $25.3 \mu \mathrm{g} / \mathrm{g}$ in the control sample, whereas it was increased to $29.3 \mu \mathrm{g} / \mathrm{g}$ in the treated sample. There was $15.81 \%$ increased of IAA content in mustard roots after biofield energy treatment. Furthermore, the level of IAA in mustard shoots was $17.7 \mu \mathrm{g} / \mathrm{g}$ in control sample, whereas it was slightly increased to $20.0 \mu \mathrm{g} / \mathrm{g}$ in the treated group. The data showed $12.99 \%$ increase in the IAA content in the shoots of biofield treated group. The growth of roots and shoots of mustard seedling was well increased due to over production of plants growth substance IAA. These findings were well corroborated with the literature [33, 34]. Based on the findings, it is assumed that the increased IAA content after biofield energy treatment in both roots and shoots might be helpful for their growth and overall development of plants.

\subsection{Random Amplified Polymorphic DNA (RAPD) Analysis}

The polymorphic DNA is responsible for giving the information about genetic marker due to its selectively of neutral nucleotide sequence and distinct genomes pattern [35, 36]. Here, RAPD was used as a DNA fingerprinting technique for evaluation of mustard seeds. The control and treated samples were evaluated based on their various RAPD patterns. It is very simple to detect because there is no need of DNA sequence information or synthesis of specific primers. It is a preferred tool being used nowadays to correlate the genetic similarity or mutations between species. The simplicity and wide field acceptability of RAPD technique due to short nucleotide primers, which were unrelated to known DNA sequences of the target organism [37]. The DNA fingerprinting by RAPD method was performed using five primers in the control and treated samples. The polymorphic bands are marked by arrows as shown in Fig. 2. 


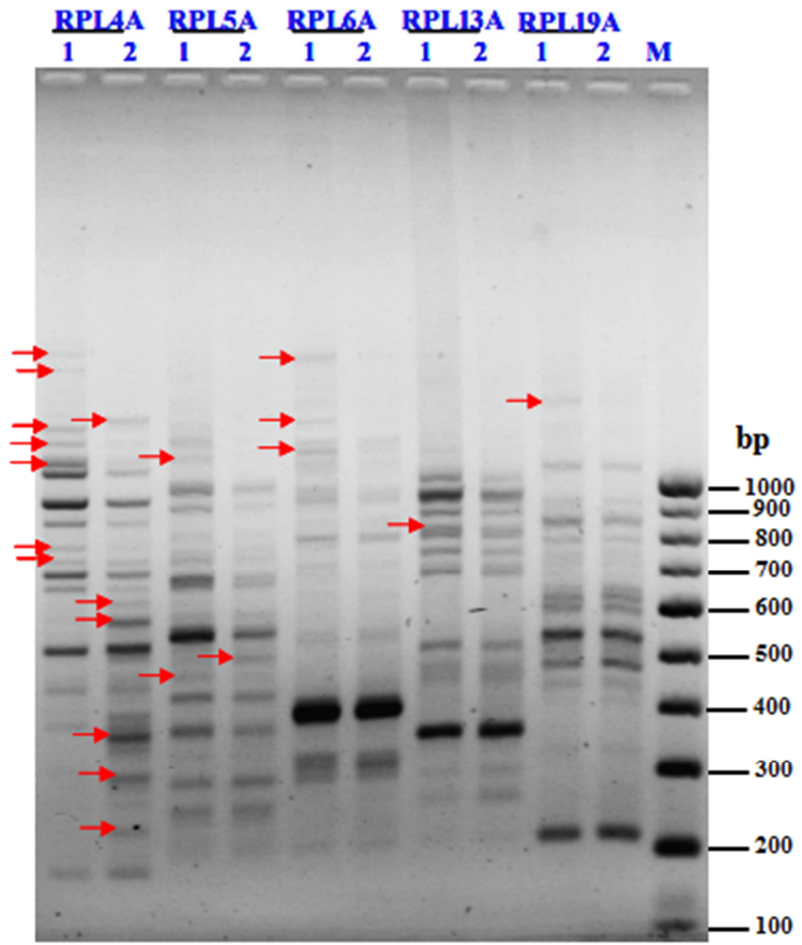

Figure 2. Random amplified polymorphic-DNA (RAPD) profile of mustard seeds (Brassica juncea) generated using Genei five RAPD primers, RPL 4A, RPL 5A, RPL 6A, RPL 13A and RPL 19A. 1: Control; 2: Treated; M: $100 \mathrm{bp}$ DNA Ladder.

The RAPD patterns of treated sample showed some unique and dissimilar patterns. DNA polymorphism analyzed by the RAPD analysis was presented in Table 3. The level of true polymorphism in treated sample was observed at $59 \%$ with RPL $4 \mathrm{~A}$ primer, at $21 \%$ with RPL $5 \mathrm{~A}$ primer, at $30 \%$ with RPL 6A primer, at $10 \%$ with RPL 13A primer and at $11 \%$ with RPL 19A primer with respect to the control sample. The polymorphism was detected between control and treated samples. The percentage of true polymorphism was observed between control and treated samples of mustard seed an average $26 \%$ after the biofield energy treatment.

Table 3. DNA polymorphism analyzed by random amplified polymorphicDNA (RAPD) analysis of mustard seeds (Brassica juncea).

\begin{tabular}{llllll}
\hline \multirow{2}{*}{ S. No. } & Primer & $\begin{array}{l}\text { Band } \\
\text { Scored }\end{array}$ & $\begin{array}{l}\text { Common Band } \\
\text { in Control and } \\
\text { Treated }\end{array}$ & \multicolumn{2}{c}{ Unique Band } \\
\cline { 6 - 6 } & & Control & Treated \\
\hline 1 & RPL 4A & 21 & 8 & 7 & 6 \\
2 & RPL 5A & 13 & 8 & 2 & 1 \\
3 & RPL 6A & 8 & 4 & 3 & - \\
4 & RPL 13A & 8 & 8 & 1 & - \\
5 & RPL 19A & 10 & 8 & 1 & - \\
\hline
\end{tabular}

- , No band

The highest change in DNA sequence (46\%) was observed in the treated group with RPL 4A primer as compared to the control. The lowest change was found in the treated group with RPL 13A primer as compared to the control. Biofield energy treatment could be responsible to improve the GSH and IAA content in mustard shoots and roots. Based on the findings of growth germination pattern of seedling, GSH level, and IAA content followed by RAPD analysis there was positive impact of Mr. Trivedi's biofield energy treatment on the seeds of $B$. juncea. Based on these results, it is expected that biofield energy treatment has the scope to be an alternative approach related to improve the plant growth, development and simultaneously could reduce the pathogenicity.

\section{Conclusions}

Based on the study outcome, the biofield energy treated $B$. juncea showed faster (on day 5) and 100\% germination as compared to the control (between day 7-10,65\%). Moreover, the GSH content in treated sample was increased significantly $(p<0.001)$ by $206.72 \%$ of $B$. juncea leaves as compared with their respective control. Apart from this, the plants growth regulating constituent IAA was also increased by $15.81 \%$ in mustard roots, while $12.99 \%$ increased in mustard shoots as compared to the control. RAPD analysis data of the treated sample showed an average $26 \%$ of polymorphism among the primers as compared to the control. In conclusion, the present investigation demonstrates that $\mathrm{Mr}$. Trivedi's unique biofield treatment could be utilized as an alternate therapeutic approach concurrent with other existing therapy to improve the productivity of mustard in the field of agriculture in the near future.

\section{Abbreviations}

ROS: Reactive oxygen species; ASC-GSH: Ascorbateglutathione; PCR: Polymerase chain reaction; NCCIH: National Center for Complementary and Integrative Health; CAM: Complementary and Alternative Medicine; RAPD: Random amplified polymorphic DNA; TCA: Trichloroacetic acid; CTAB: Cetyl-trimethyl-ammonium bromide; IAA: Indole acetic acid.

\section{Acknowledgements}

Financial assistance from Trivedi science, Trivedi testimonials and Trivedi master wellness is gratefully acknowledged. Authors thank Monad Nanotech Pvt. Ltd., Mumbai, for their support.

\section{References}

[1] Dubie J, Stancik A, Morra M, Nindo C (2013) Antioxidant extraction from mustard (Brassica juncea) seed meal using high-intensity ultrasound. J Food Sci 78: E542-E548.

[2] Tsuruo I, Yoshida M, Hata T (1967) Studies on the myrosinase in mustard seed part I. the chromatographic behaviors of the myrosinase and some of its characteristics. Agr Biol Chem 31: 18-26.

[3] Bones AM, Rossiter JT (1996) The myrosinase-glucosinolate system, its organization and biochemistry. Physiol Plant 97: 194-208. 
[4] Bassan P, Sharma S, Arora S, Vig AP (2013) Antioxidant and in vitro anti-cancer activities of Brassica juncea (L.) Czern. seeds and sprouts Int J Pharma Sci 3: 343-349.

[5] Amarowicz R, Wanasundara UN, Karamac M, Shahidi F (1996) Antioxidant activity of ethanolic extract of mustard seed. Nahrung 40: 261-263.

[6] Rance F, Dutau G, Abbal M (2000) Mustard allergy in children. Allergy 55: 496-500.

[7] Morisset M, Moneret-Vautrin DA, Maadi F, Fremont S, Guenard L, et al. (2003) Prospective study of mustard allergy: first study with double-blind placebo-controlled food challenge trials (24 cases). Allergy 58: 295-299.

[8] Parti RS, Deep V, Gupta SK (2003) Effect of salinity on lipid components of mustard seeds (Brassica juncea L.) Plant Food Hum Nutr 58: 1-10.

[9] Munns R, Tester M (2008) Mechanisms of salinity tolerance. Ann Rev Plant Biol 59: 651-681.

[10] Dionisio-Sese ML, Tobita S (1998) Antioxidant responses of rice seedlings to salinity stress. Plant Sci 135: 1-9.

[11] Mittler R, Vanderauwera S, Gollery M, Van Breusegem F (2004) Reactive oxygen gene network of plants. Trends Plant Sci 9: 490-498.

[12] Asada K (2006) Production and scavenging of reactive oxygen species in chloroplasts and their functions. Plant Physiol 141: 391-396.

[13] Noctor G, Foyer CH (1998) Ascorbate and glutathione: Keeping active oxygen under control. Annu Rev Plant Physiol Plant Mol Biol 49: 249-729.

[14] Khan MA, Rabbani MA, Munir M, Ajmal SK, Malik MA (2008) Assessment of genetic variation within Indian mustard (Brassica juncea) germplasm using random amplified polymorphic DNA markers. J Integr Plant Biol 50: 385-392.

[15] Barnes PM, Powell-Griner E, McFann K, Nahin RL (2004) Complementary and alternative medicine use among adults: United States, 2002. Adv Data 343: 1-19.

[16] Shinde V, Sances F, Patil S, Spence A (2012) Impact of biofield treatment on growth and yield of lettuce and tomato. Aust J Basic Appl Sci 6: 100-105.

[17] Sances F, Flora E, Patil S, Spence A, Shinde V (2013) Impact of biofield treatment on ginseng and organic blueberry yield. Agrivita J Agric Sci 35.

[18] Lenssen AW (2013) Biofield and fungicide seed treatment influences on soybean productivity, seed quality and weed community. Agricultural Journal 8: 138-143.

[19] Nayak G, Altekar N (2015) Effect of biofield treatment on plant growth and adaptation. J Environ Health Sci 1: 1-9.

[20] Trivedi MK, Tallapragada RM, Branton A, Trivedi D, Nayak G, et al. (2015) Characterization of physical, spectral and thermal properties of biofield treated 1,2,4-Triazole. J Mol Pharm Org Process Res 3: 128.

[21] Moron MS, Depierre JW, Mannervik B (1979) Levels of glutathione, glutathione reductase and glutathione Stransferase activities in rat lung and liver. Biochim Biophys Acta 582: 67-78.

[22] Tang YW, Bonner J (1947) The enzymatic inactivation of indoleacetic acid. I. Some charasteristics of the enzyme contained in pea seedlings. Arch Biochem 13: 11-25.

[23] Green MR, Sambrook J (2012) Molecular cloning: A laboratory manual. (3rdedn), Cold Spring Harbor, N.Y. Cold Spring Harbor Laboratory Press.

[24] Borges A, Rosa MS, Recchia GH, QueirozSilva JRD, Bressan EDA, et al. (2009) CTAB methods for DNA extraction of sweet potato for microsatellite analysis. Sci Agric (Piracicaba Braz) 66: 529-534.

[25] Welsh JW, McClelland M (1990) Fingerprinting genomes using PCR with arbitrary primers. Nucleic Acids Res 18: 7213-7218.

[26] Turk MA, Tawaha AM (2002) Inhibitory effects of aqueous extracts of barley on germination and growth of lentil. Pak J Agron 1: 28-30.

[27] Sharma P, Sardana V, Banga SS (2013) Salt tolerance of Indian mustard (Brassica juncea) at germination and early seedling growth. Environ Exp Biol 11: 39-46.

[28] Rausch T, Wachter A (2005) Sulfur metabolism: A versatile platform for launching defense operations. Trend Plant Sci 10: 503-509.

[29] Gagandeep, Dhiman M, Mendiz E, Rao AR, Kale RK (2005) Chemopreventive effects of mustard (Brassica compestris) on chemically induced tumorigenesis in murine forestomach and uterine cervix. Hum Exp Toxicol 24: 303-312.

[30] Zhu YL, Pilon-Smits EAH, Jouanin L, Terry N (1999) Overexpression of glutathione synthetase in Indian mustard enhances cadmium accumulation and tolerance. Plant Physiol 119: 73-80.

[31] Black H (1995) Absorbing possibilities: Phytoremediation. Environ Health Perspect 103: 1106-1108.

[32] Yamada $T$ (1993) The role of auxin in plant-disease development. Annu Rev Phytopathol 31: 253-273.

[33] Morris RO (1986) Genes specifying auxin and cytokinin biosynthesis in phytopathogens. Annu Rev Plant Physiol 37: 509-538.

[34] Chen Q, Qi WB, Reiter RJ, Wei W, Wang BM (2009) Exogenously applied melatonin stimulates root growth and raises endogenous indoleacetic acid in roots of etiolated seedlings of Brassica juncea. J Plant Physiol 166: 324-328.

[35] Kimura M (1983) The neutral theory of molecular evolution. Cambridge Univ. Press, Cambridge.

[36] Bretting PK, Widrlechner MP (1995) Genetic markers and plant genetic resource management. John Wiley \& Son Inc. Canada.

[37] Williams JG, Kubelik AR, Livak KJ, Rafalski JA, Tingey SV (1990) DNA polymorphisms amplified by arbitrary primers are useful as genetic markers. Nucleic Acids Res 18: 6531-6535. 